Knight, E. C., N. A. Mahony, and D. J. Green. 2014. Crop type influences edge effects on the reproduction of songbirds in sagebrush habitat near agriculture. Avian Conservation and Ecology 9(1): 8. http://dx.doi.org/10.5751/ACE-00662-090108

Copyright (C) 2014 by the author(s). Published here under license by the Resilience Alliance.

Research Paper

\title{
Crop type influences edge effects on the reproduction of songbirds in sagebrush habitat near agriculture
}

\author{
Elly C. Knight ${ }^{1}$, Nancy A. Mahony ${ }^{2}$ and David J. Green ${ }^{1}$ \\ ${ }^{1}$ Simon Fraser University, ${ }^{2}$ Environment Canada
}

\begin{abstract}
Extensive fragmentation of the sagebrush shrubsteppe of western North America could be contributing to observed population declines of songbirds in sagebrush habitat. We examined whether habitat fragmentation impacts the reproduction of songbirds in sagebrush edge habitat near agriculture, and if potential impacts vary depending on the adjacent crop type. Specifically, we evaluated whether nest abundance and nest survival varied between orchard edge habitat, vineyard edge habitat, and interior habitat. We then examined whether the local nest predator community and vegetation could explain the differences detected. We detected fewer nests in edge than interior habitat. Nest abundance per songbird was also lower in edge than interior habitat, although only adjacent to vineyards. Nest predation was more frequent in orchard edge habitat than vineyard edge or interior habitat. Predators identified with nest cameras were primarily snakes, however, reduced nest survival in orchard edge habitat was not explained by differences in the abundance of snakes or any other predator species identified. Information theoretic analysis of daily survival rates showed that greater study plot shrub cover and lower grass height at nests were partially responsible for the lower rate of predation-specific daily nest survival rate (PDSR) observed in orchard edge habitat, but additional factors are likely important. Results of this study suggest that different crop types have different edge effects on songbirds nesting in sagebrush shrubsteppe, and that these reproductive edge effects may contribute to observed declines of these species. Habitat managers should avoid the creation of new orchard-sagebrush habitat edges to avoid further impacts on already declining songbird populations.
\end{abstract}

\section{Effet de bordure sur la reproduction de passereaux dans des milieux d'armoises variable selon le type de culture adjacente}

RÉSUMÉ. La fragmentation à grande échelle de la steppe arbustive à armoises de l'ouest de l'Amérique du Nord contribue peut-être aux déclins observés des passereaux des milieux d'armoises. Nous avons examiné si la fragmentation avait un impact sur la reproduction des passereaux dans des milieux d'armoises en bordure de milieux agricoles, et si les effets potentiels variaient selon le type de culture adjacente. Plus particulièrement, nous avons évalué si le nombre de nids et leur survie différaient entre les milieux de bordure de vergers, les milieux de bordure de vignobles et les milieux d'intérieur. Nous avons ensuite examiné si la communauté locale de prédateurs de nids et la végétation pouvaient expliquer les différences détectées. Nous avons trouvé moins de nids dans les milieux de bordure que dans les milieux d'intérieur. Le nombre de nids par espèce était également plus faible dans les bordures par rapport aux milieux d'intérieur, mais ce, seulement près des vignobles. La prédation des nids était plus fréquente dans les bordures de vergers que dans les bordures de vignobles ou les milieux d'intérieur. Les prédateurs identifiés par caméra au-dessus des nids étaient surtout des serpents. Toutefois, la survie plus faible des nids dans les bordures de vergers n'a pas pu être expliquée à partir des différences du nombre de serpents ou de tout autre prédateur identifié. L'analyse par théorie de l'information des taux de survie quotidiens a montré que le couvert arbustif plus élevé dans nos parcelles-échantillons et la plus petite taille des herbacées aux nids étaient en partie responsables du taux moins élevé de survie quotidien des nids spécifique à la prédation observée dans les bordures de vergers, mais d'autres facteurs importants agissent vraisemblablement. Les résultats de notre étude montrent que les différents types de culture ont des effets de bordure variés sur les passereaux nichant dans la steppe arbustive à armoises, et que ces effets de bordure sur la reproduction participent peutêtre aux déclins observés de ces espèces. Les gestionnaires d'habitat devraient éviter de créer de nouveaux milieux de bordure vergersarmoises afin de prévenir davantage d'effets négatifs sur des populations de passereaux déjà en déclin.

Key Words: agriculture; conservation; edge effects; fragmentation; nest survival; sagebrush; songbird

\section{INTRODUCTION}

Anthropogenic habitat fragmentation continues to increase the proportion of edge habitat in terrestrial landscapes. When edge habitat is created, the ecological communities present are exposed to different biotic and abiotic processes (Ewers and Didham 2006, Fischer and Lindenmayer 2007). The impact of these processes, or "edge effects" (Leopold 1933) has been studied extensively in temperate breeding birds, and several types of edge effects have been detected. The presence of edges can influence habitat choice, with specialist species often less abundant in edge habitat than away from edges (Ewers and Didham 2006). The individuals that reside nearer to edges can have lower pairing success (Van Horn et al. 1995, Bayne and Hobson 2001), or suffer higher nest predation (reviewed by Lahti 2001, Batáry and Báldi 2004, 
Stephens et al. 2004). Most of the early edge effect studies indicated nest predation is consistently higher near habitat edges (Andrén et al. 1985, Paton 1994, Major and Kendal 1996). However, recent studies suggest that an edge effect on nest predation is often not detected and can vary with many factors (Hartley and Hunter 1998, Sisk and Battin 2002, Batáry and Báldi 2004). For example, edge effects appear to be more prominent in landscapes with high levels of anthropogenic fragmentation (Donovan et al. 1997, Lahti 2001). Given the number of factors that can influence edge effects, reviews suggest potential edge effects on nest predation should be studied on a regional basis (Sisk and Battin 2002, Stephens et al. 2004).

The most commonly proposed explanation for an edge effect on nest predation is increased abundance of nest predators in edge habitat (Chalfoun et al. 2002, Lahti 2009, Spanhove et al. 2009). However, without identification and quantification of the abundance of the dominant nest predator, this explanation remains speculative. Furthermore, it is difficult to understand why predators might be more abundant in edge habitat without also understanding the life history of the dominant nest predator. Studies have traditionally ignored predator identity because it was difficult to record nest predation events (Lahti 2009). Recent studies that use modern camera technology to identify nest predators have had more success explaining the presence or absence of edge effects on nest predation. For example, an overall absence of an edge effect on nest predation can occur because predation by one species in edge habitat is offset by that of another species in interior habitat (Benson et al. 2010, Cox et al. 2012).

Conversion of land for agriculture is a leading cause of global habitat fragmentation (Foley et al. 2005). An edge effect on nest predation is more often, although not always, detected near agricultural edges than other edge types (Andrén 1995, but see Davis et al. 2006). Additionally, predators are often more abundant in edge habitat near agriculture than other land uses or interior habitat (Chalfoun et al. 2002). Agricultural edge habitat may have high nest predation rates because predators are attracted to supplemental food sources or vegetation structure within the adjacent crop (Chalfoun et al. 2002). Thus, the strength of edge effects should also vary with crop type because both food source and vegetation structure vary widely among crops. Some studies and reviews to date may have failed to detect edge effects on nest predation because they have generalized across crop types (e.g., Lahti 2001).

Extensive habitat fragmentation by agriculture has contributed to the imperilment of sagebrush shrubsteppe habitats in North America. Many of the species that inhabit the sagebrush shrubsteppe are also imperilled and show apparent population declines (Knick et al. 2003, Wisdom et al. 2003, Sauer et al. 2014). Habitat fragmentation is considered a contributing factor to these declines because predation rates of songbird nests are generally higher in shrubsteppe landscapes fragmented by agriculture than unfragmented landscapes (Vander Haegen et al. 2002, Vander Haegen 2007). This landscape level pattern may arise because of edge effects on nest predation in fragmented landscapes (Bender et al. 1998, Ries et al. 2004, Fletcher et al. 2007).

In this study, we examined agricultural edge effects on the breeding success of four species of songbirds in sagebrush habitat, and investigated whether edge effects varied with crop type of the adjacent agriculture, orchard, or vineyard. First, we evaluated whether songbirds in sagebrush habitat nested more frequently in edge or interior sagebrush habitat. We then tested whether nest predation was more frequent in edge habitat than interior habitat. We used remote cameras placed at natural nests in the sagebrush shrubsteppe to identify nest predator species and used this information to evaluate whether differences in nest predation rate could be attributed to the abundance of known nest predators.

\section{METHODS}

\section{Study area}

We studied songbirds breeding in sagebrush shrubsteppe habitat in the Okanagan region of British Columbia, Canada and Washington, USA from May to August 2011 and 2012 (Fig. 1A). Sagebrush shrubsteppe habitat is characterized by big sagebrush (Artemisia tridentata) and bunch grasses. The Okanagan is the northernmost region of the shrubsteppe that extends across the intermountain west of North America. Human activities exert high pressure on the sagebrush habitat in the Okanagan and approximately $35 \%$ has been converted to other land uses such as orchards and ground crops (USA: 38\% Dobler et al. 1996, Canada: 33\% Iverson et al. 2008). Currently, both sagebrush habitat and orchard areas are being converted to vineyards to meet increasing consumer demand for wine.

Fig. 1. A. Sites for studying the songbird community in sagebrush shrubsteppe habitat in the Okanagan region of British Columbia, Canada, and Washington, USA. B. Study site schematic overlaid on imagery of a real study site. Each study site consisted of a pair of study plots: one plot adjacent to agriculture (edge) and one away from agriculture (interior).

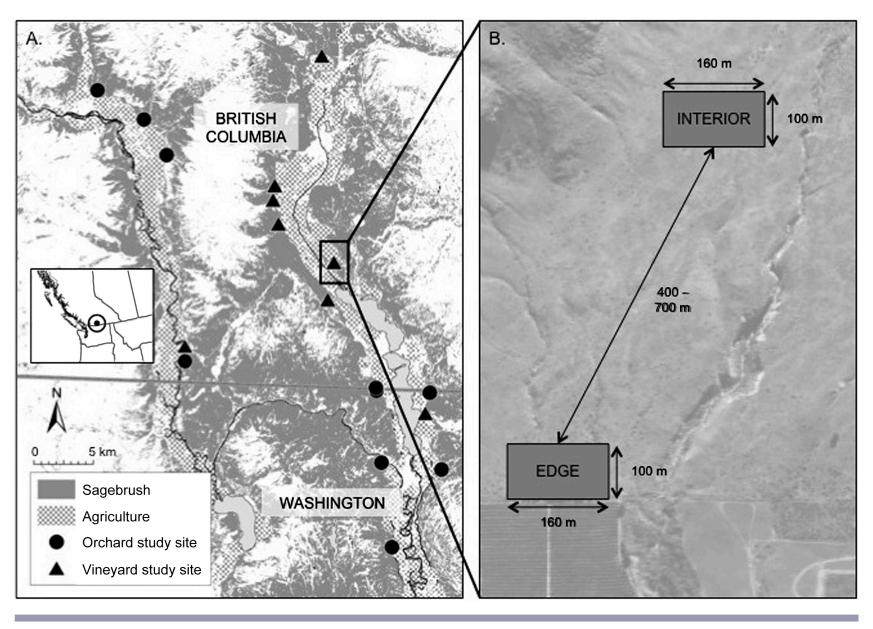

\section{Study species}

The suite of songbirds that nest in the Okanagan sagebrush shrubsteppe include Brewer's Sparrows (Spizella breweri), Lark Sparrows (Chondestes grammacus), Vesper Sparrows (Pooecetes gramineus), and Western Meadowlarks (Sturnella neglecta). Population trends for these species in the Great Basin bird conservation region are $-0.8 \%,-1.0 \%,-0.8 \%,-1.1 \%$ change per year, respectively (Sauer et al. 2014). The last three species are all 
open-cup ground nesters that conceal their nests at the base of bunchgrasses, small shrubs, or large forbs (Pitkin and Quattrini 2010). In contrast, Brewer's Sparrows place their open-cup nests off the ground in big sagebrush (Rotenberry et al. 1999).

\section{Study plots}

We selected study sites in patches of sagebrush shrubsteppe that were adjacent to agriculture, that were large enough to include interior habitat at least $400 \mathrm{~m}$ from agriculture in all directions, that had similar vegetation across the study site, and where we were given permission to access the property. In total, breeding of songbirds was monitored at 18 sites, each consisting of a pair of $160 \mathrm{~m}$ by $100 \mathrm{~m}$ study plots (Fig. 1A, 1B). Plot size was chosen to ensure observers would be able to adequately survey songbirds, predators, and vegetation at each plot. Each pair consisted of one plot in sagebrush shrubsteppe adjacent to agriculture ("edge habitat") and one plot 400 - $700 \mathrm{~m}$ into shrubsteppe habitat away from anthropogenic land uses ("interior habitat"). Half of the plots were surveyed in 2011, and the remainder in 2012. Ten edge plots were situated adjacent to orchards, and eight adjacent to vineyards to test for different edge effects among agricultural types (Fig. 1A).

\section{Nest surveys}

Plots were searched for songbird nests with a systematic, constant effort strategy to avoid bias at any given plot. Each plot was searched for two hours every four days using a combination of systematic and observational techniques. Systematic nest searches were conducted by walking transects while waving a wooden rod to flush birds. Observational searches using behavioral cues of adult birds were conducted on all study species individuals for which the study plot made up at least a portion of their territory to maximize the number of nests found. Upon discovery, the age of the contents of each nest was estimated by candling eggs (Lokemoen and Koford 1996), or aging nestlings based on published descriptions (Dawson and Evans 1960, Baepler 1968, Rotenberry et al. 1999, Davis and Lanyon 2008). We confirmed that observers were able to candle incubated eggs to within two days of the correct age using information on mean incubation period and the hatch days of aged nests. Each nest found was subsequently checked every four days. Nests were considered depredated if the nest was destroyed, indicating a predation event had occurred. Nests were also considered depredated if there was no indication of fledglings in the area and the nest was found empty more than one day before the predicted fledge date. Nests were considered successful if the nest was found empty within one day of the predicted fledge date and parental behavior indicated fledglings were present in the area.

\section{Nest predator detection}

Bushnell Trophy Cam trail cameras (model \#119466C) were deployed at 35 songbird nests to identify the species of nest predators in the region. Cameras were only deployed at nests with complete clutches to minimize abandonment. Each camera was camouflaged with sage and grass and positioned at least $30 \mathrm{~cm}$ from the nest. If the nest parents did not resume incubation or parental care within one hour following deployment, the camera was removed and installation was attempted on another visit. Camera batteries and 32 GB SD cards were changed every four days following successful deployment. We reviewed the nest camera footage to confirm the fate of all nests with cameras and identify the species of nest predator responsible for any nest predation events.

\section{Nest predator abundance}

We measured the abundance or presence/absence of potential predator species of songbird nests at each plot in the sagebrush shrubsteppe. Relative abundance of small mammals at each plot was measured with track tubes, which collect footprints using a food bait (adapted from Mabee 1998, Glennon et al. 2002, Wiewel et al. 2007). Two replicate sets of track tubes were set out at each plot with 36 days between the two sets. There were 24 tubes spaced $30 \mathrm{~m}$ apart from each other on an $8 \times 4$ grid in each replicate set. Track tubes were $30 \mathrm{~cm}$ lengths of vinyl white downspout with felt pads glued at either entrance, and a length of clear adhesive drawer liner to collect prints. Each felt pad was saturated with a mixture of mineral oil and carbon black powder. Tubes were baited with a small amount of peanut butter on the inner ceiling of the tube and set under a shrub. The tubes were then left at each study plot for four days to collect prints. All prints were identified as mouse (Superfamily Muroidea) because faint or overlapping prints were often indistinguishable to species. An abundance index was calculated for each replicate set at each plot by dividing the number of track tubes set out by the number of tubes that collected prints. The abundance indices from the two replicate sets of track tubes were highly correlated ( $\mathrm{r}=0.767, P<0.001)$, so we averaged the two replicate sets of track tubes at each plot to calculate the abundance index for each plot.

Presence or absence of medium and large sized mammals (black bear [Ursus americanus], coyote [Canis latrans], domestic cat [Felis catus], domestic cow [Bos primigenius], long-tailed weasel [Mustela frenata], raccoon [Procyon lotor], yellow-pine chipmunk [Noetamias amoenus]) at each plot was estimated using a combination of incidental observations and track stations (adapted from Kuehl and Clark 2002). Incidental observations of scat, dens, or live individuals were recorded from 1 May 1 to 31 July. Equal time was spent at each plot by each observer to avoid any observer or site bias in detection ( $35.8 \pm 1.8$ hours per plot). In addition, four track stations were set up at each study plot from early May to 15 July. Track stations were $1 \mathrm{~m} \mathrm{x} 1 \mathrm{~m}$ squares of fine sand with a round white disc at the center to attract the attention of animals passing by. Tracks left in the sand when animals investigated this novel object were photographed, identified to species, and cleared every four days. A species was considered present at a plot if an incidental observation was recorded or if track station prints could be unambiguously identified to species.

Avian predators were surveyed with point counts. One point count was conducted each day by each observer to prevent double counting birds at adjacent edge and interior study plots. To avoid observer bias, observers rotated through study plots so that point counts were conducted every eight days at each plot for a total of eight counts per plot. Each point count lasted 10 minutes and was conducted within one hour of sunrise. Observers recorded all birds detected by sight or sound within $100 \mathrm{~m}$ of the center of the study plot (see Knight 2013 for details on point count methods). The maximum number of individuals detected during a single 
point count was used as the abundance metric for each species (Nur et al. 1999). Birds that were not considered to be using the habitat were not included in analysis.

Snake abundance was measured using standardized searches and combined with incidental observations at each plot. Standardized searches covered the entire plot during a 45 - 60 minute search every four days. Observers walked back and forth across the plot in $10 \mathrm{~m}$ wide transects moving vegetation with a $1.5 \mathrm{~m}$ wooden rod to detect any snakes present. The first plot to be searched at each site was alternated between edge and interior after every search day to avoid any time of day bias. Incidental observations were recorded while observers were conducting other activities at each plot. Approximately equal time was spent at each plot to avoid plot bias (35.8 \pm 1.8 hours per plot), however snake abundance per species was divided by time spent at each plot to account for any variation.

\section{Vegetation}

We measured the local vegetation at each plot along four $100 \mathrm{~m}$ transects that spanned the width of the plot and were spaced 50 $\mathrm{m}$ apart. We measured the percent linear cover of shrubs using the line intercept method (Kaiser 1983). We also recorded the maximum height of each shrub along each transect. We estimated percent cover of all forb and grass species, and percent cover of ground cover type (bare ground, litter, i.e., dead vegetation, or biocrust) with a standard $20 \mathrm{~cm} \times 50 \mathrm{~cm}$ Daubenmire plot at every $10 \mathrm{~m}$ along each transect (Daubenmire 1959). Maximum grass and standing litter height were also recorded at every $10 \mathrm{~m}$ along each transect. We averaged each vegetative characteristic to obtain a value at each study plot. These vegetation survey methods follow methods previously used in the study area to allow for direct comparison in future studies (Paczek and Krannitz 2004, Harrison and Green 2010). Vegetation at each plot was measured at the end of the breeding season to avoid disturbing any songbird nests.

We also measured the vegetation around each nest after the nest had failed or successfully fledged young. We calculated percent visibility as the average visibility of the nest from one metre in four cardinal directions. We measured the maximum grass or forb height within $10 \mathrm{~cm}$ of the nest, and the distance to the nearest shrub cover.

\section{Statistical analysis}

We tested for differences in nest abundance across habitat types before and after controlling for total songbird abundance. Songbird abundance was recorded during point counts conducted for avian predators and was controlled for by dividing the number of nests found in each plot by the summed abundance of the four study species in each plot. Total songbird abundance per species was measured as the maximum number of individuals detected in a single 10-minute point count.

We compared both nest abundance metrics between interior habitat and edge habitat (orchard edges and vineyard edges combined) with a paired Wilcoxon signed rank test. To test for differences between agricultural types, we compared orchard edge habitat to the paired orchard interior habitat, and vineyard edge habitat to the paired vineyard interior habitat with two additional paired Wilcoxon signed rank tests. A third set of similar analyses were conducted to test for differences across the habitat types in the abundance of known predator groups (mammal, bird, snake) and predator species (Black-billed Magpies [Pica hudsonia], Western Meadowlarks, yellow-bellied racers [Coluber constrictor], and gopher snakes [Pituophis catenfir]). A fourth set of paired Wilcoxon signed rank tests were conducted to test among the habitat types for differences in local vegetative characteristics that have previously been shown to be important for songbirds in sagebrush habitat (shrub height, shrub cover, grass height, exotic grass cover, native grass cover, native forb cover, standing litter height, litter cover, bare ground cover, biocrust cover). Finally, we tested for differences in nest vegetation (grass height, distance to the nearest shrub, visibility) between nests in edge habitat and nests in interior habitat with Wilcoxon signed rank tests.

We used the logistic exposure method (Shaffer 2004) to estimate the predation-specific daily nest survival rate (PDSR) of songbirds in sagebrush habitat. The logistic exposure method maximizes use of nest survival data by treating each nest check interval as a discrete trial and uses a customized logistic link function in a generalized linear model (GLM) framework to allow for exposure periods to vary. We excluded any nests that failed because of abandonment, failure to hatch, or inclement weather because we were primarily interested in edge effects on predation and because few nests failed because of causes other than predation. To ensure an adequate sample size, we pooled samples from all four study species, but considered the effect of species in our model selection. We initially used a generalized linear mixed model (GLMM) framework to calculate PDSR because it allowed us to account for any site and parental effects through the inclusion of site and nest identity terms as random factors, but ultimately chose to use a simpler GLM framework that allowed for calculation of Akaike information criterion (AIC) because the GLMM and GLM frameworks provided similar results. The length of the final nest check was constrained to the average day a nest of that species would fledge (Dawson and Evans 1960, Baepler 1968, Rotenberry et al. 1999, Davis and Lanyon 2008).

We used an information theoretic approach to examine PDSR. To minimize the number of variables in any given model, we used a multistep variable inclusion approach to build a predictive model of PDSR. Within each step, a global model was created with all terms of interest and competed against simpler models (Table 1). We assessed relative support using AIC values corrected for small sample sizes $\left(\mathrm{AIC}_{\mathrm{c}}\right)$. Steps one and two tested for any species, camera, or temporal effects on PDSR that we might want to control for in later model testing. The next three steps tested for effects of variables that could explain an edge effect on PDSR. The third step of model selection evaluated whether predator abundance explained songbird nest fate. The fourth step of model selection evaluated whether local (plot level) vegetation characteristics explained nest fate. This step only considered vegetation characteristics that varied between habitat type (see above for details on paired Wilcoxon signed rank tests; Table 2) because we were interested in whether differences in nest fate between habitat types were due to vegetation differences. The fifth step examined whether nest fate was influenced by vegetation characteristics at the nest site. In each step, we selected any variables that were present in at least two of the top three models for further analysis (Table 3 ). 
Table 1. Terms considered to explain predation-specific daily nest survival rate (PDSR) and nestling condition of songbirds in sagebrush habitat. Terms were selected in a multistep hierarchical process using an information theoretic approach.

\begin{tabular}{|c|c|c|c|}
\hline Term & Class & Description & Levels \\
\hline \multicolumn{4}{|c|}{ Step 1. Species effects } \\
\hline Species & Factor & Species of nest & $\begin{array}{l}\text { Brewer's Sparrow, } \\
\text { Lark Sparrow, } \\
\text { Vesper Sparrow, } \\
\text { Western Meadowlark }\end{array}$ \\
\hline Type & Factor & Type of nest substrate & Shrub, Ground \\
\hline Camera & Factor & Presence or absence of nest camera on nest & Present, Absent \\
\hline
\end{tabular}

Step 2. Temporal effects

$\begin{array}{ll}\text { Day } & \text { Integer } \\ \text { Day2 } & \text { Integer } \\ \text { Year } & \text { Factor }\end{array}$

Step 3a. Predator effects by group

$\begin{array}{ll}\text { Mammal } & \text { Integer } \\ \text { Bird } & \text { Integer } \\ \text { Snake } & \text { Numeric } \\ \text { Mice } & \text { Numeric }\end{array}$

Step 3b. Predator effects by species

$\begin{array}{ll}\text { BBMA } & \text { Integer } \\ \text { WEME } & \text { Integer } \\ \text { Racer } & \text { Numeric } \\ \text { Gopher } & \text { Numeric }\end{array}$

Gopher Numeric

Step 4. Plot vegetation effects

Exotic Grass \% Numeric

Native Grass $\% \quad$ Numeric

Shrub\% Numeric

ShrubHt Numeric

Step 5. Nest vegetation effects

GrassHt Numeric

ShrubD Numeric

Visibility Numeric
Day of observation (May 1 = 1).

Squared term of Day

Year of observation

2011,2012
Sum of mammalian predator species

Sum of max point count abundance of avian predators

Snakes detected per survey minute

Proportion of track tubes with mouse prints
Maximum point count abundance of Black-billed Magpies

Maximum point count abundance of Western Meadowlarks

Yellow-bellied racers seen per minute

Gopher snakes seen per minute
Percent cover of exotic grasses

Percent cover of native grasses

Percent cover of shrubs

Average height of shrubs

Brewer's Sparrows (Spizella breweri), Lark Sparrows (Chondestes grammacus), Vesper Sparrows (Pooecetes gramineus), Western Meadowlarks (Sturnella neglecta), Black-billed Magpies (Pica hudsonia), Yellow-bellied racers (Coluber constrictor), gopher snakes (Pituophis catenfir)

Next we tested for an edge effect on PDSR by comparing four models each representing a different edge-effect hypothesis including a null model (Table 4). These edge-effect hypotheses included a nest stage term to control for higher PDSR during the incubation stage. Estimates of PDSR in orchard edge habitat and in vineyard edge/interior habitat were calculated by bootstrapping the data 10000 times and fitting it to the model representing the orchard edge hypothesis. We created each bootstrap replicate by resampling from our sample of nests rather than resampling from our sample of nest checks.

Upon finding strong support for an orchard edge effect on PDSR over all other models, we tested whether any variables selected in the multistep inclusion process explained any of this edge effect (Black-billed Magpie abundance, study plot shrub cover, grass height at nest). We added the complete set of terms to the orchard and null hypothesis models. We also added each term separately to the two hypothesis models to examine the effects of each variable separately. Competing the simpler models with the full models was also important for choosing the model with the most support because AIC penalizes models with many parameters, and although some of the final terms included met our criteria for inclusion, they had little $\Delta \mathrm{IC}_{\mathrm{C}}$ support. An overall estimate of PDSR for the population was calculated by bootstrapping the entire sample of nests and fitting it to the most supported final model. 
Table 2. Local vegetation characteristics in edge and interior sagebrush habitat. Edge habitat was located adjacent to vineyard $(\mathrm{n}=8)$ or orchard $(\mathrm{n}=10)$. All sites indicates orchard and vineyard sites pooled. Differences between edge and interior sites were tested with paired Wilcoxon rank sign tests.

\begin{tabular}{|c|c|c|c|c|c|c|c|c|c|c|c|c|}
\hline \multirow[b]{2}{*}{$\begin{array}{l}\text { Vegetation } \\
\text { char. }\end{array}$} & \multicolumn{4}{|c|}{ All sites } & \multicolumn{4}{|c|}{ Orchard sites } & \multicolumn{4}{|c|}{ Vineyard sites } \\
\hline & $\begin{array}{c}\text { Edge } \\
\text { habitat } \\
\text { mean } \\
\pm \mathrm{se}\end{array}$ & $\begin{array}{c}\text { Interior } \\
\text { habitat } \\
\text { mean } \\
\pm \mathrm{se}\end{array}$ & $\mathrm{U}$ & $P$ & $\begin{array}{c}\text { Edge } \\
\text { habitat } \\
\text { mean } \\
\pm \mathrm{se}\end{array}$ & $\begin{array}{c}\text { Interior } \\
\text { habitat } \\
\text { mean } \\
\pm \mathrm{se}\end{array}$ & $\mathrm{U}$ & $P$ & $\begin{array}{c}\text { Edge } \\
\text { habitat } \\
\text { mean } \\
\pm \mathrm{se}\end{array}$ & $\begin{array}{c}\text { Interior } \\
\text { habitat } \\
\text { mean } \\
\pm \mathrm{se}\end{array}$ & $\mathrm{U}$ & $P$ \\
\hline $\begin{array}{l}\text { Shrub height } \\
\text { (cm) }\end{array}$ & $\begin{array}{l}100.56 \\
\pm 1.95\end{array}$ & $\begin{array}{l}77.35 \\
\pm 6.77\end{array}$ & 163 & $<0.01$ & $\begin{array}{r}110.04 \\
\pm 9.00\end{array}$ & $\begin{array}{l}82.26 \\
\pm 9.79\end{array}$ & 52 & 0.01 & $\begin{array}{l}105.06 \\
\pm 8.85\end{array}$ & $\begin{array}{l}97.00 \\
\pm 9.29\end{array}$ & 35 & 0.02 \\
\hline $\begin{array}{l}\text { Shrub cover } \\
(\%)\end{array}$ & $\begin{array}{r}28.80 \\
\pm 3.07\end{array}$ & $\begin{array}{l}23.53 \\
\pm 2.85\end{array}$ & 139 & 0.02 & $\begin{array}{l}34.30 \\
\pm 4.34\end{array}$ & $\begin{array}{l}28.81 \\
\pm 3.90\end{array}$ & 46 & 0.06 & $\begin{array}{l}21.94 \\
\pm 3.04\end{array}$ & $\begin{array}{l}16.92 \\
\pm 2.93\end{array}$ & 28 & 0.19 \\
\hline $\begin{array}{l}\text { Grass height } \\
(\mathrm{cm})\end{array}$ & $\begin{array}{c}38.48 \\
\pm 1.61\end{array}$ & $\begin{array}{l}36.06 \\
\pm 1.52\end{array}$ & 113 & 0.25 & $\begin{array}{l}37.24 \\
\pm 2.57\end{array}$ & $\begin{array}{l}37.09 \\
\pm 2.16\end{array}$ & 33 & 0.62 & $\begin{array}{l}40.02 \\
\pm 1.72\end{array}$ & $\begin{array}{l}34.77 \\
\pm 2.18\end{array}$ & 26 & 0.31 \\
\hline $\begin{array}{l}\text { Exotic grass } \\
\text { cover }(\%)\end{array}$ & $\begin{array}{l}19.83 \\
\pm 3.02\end{array}$ & $\begin{array}{l}11.38 \\
\pm 2.35\end{array}$ & 143 & 0.01 & $\begin{array}{l}20.79 \\
\pm 4.33\end{array}$ & $\begin{array}{l}9.84 \\
\pm 3.49\end{array}$ & 49 & 0.03 & $\begin{array}{l}18.63 \\
\pm 4.40\end{array}$ & $\begin{array}{l}13.30 \\
\pm 3.12\end{array}$ & 27 & 0.25 \\
\hline $\begin{array}{l}\text { Native grass } \\
\text { cover }(\%)\end{array}$ & $\begin{array}{l}14.94 \\
\pm 1.70\end{array}$ & $\begin{array}{l}18.96 \\
\pm 2.01\end{array}$ & 42 & 0.06 & $\begin{array}{l}14.47 \\
\pm 2.21\end{array}$ & $\begin{array}{l}21.22 \\
\pm 3.25\end{array}$ & 3 & 0.01 & $\begin{array}{l}15.52 \\
\pm 2.79\end{array}$ & $\begin{array}{l}16.12 \\
\pm 1.71\end{array}$ & 17 & 0.95 \\
\hline $\begin{array}{l}\text { Native forb } \\
\text { cover }(\%)\end{array}$ & $\begin{array}{l}15.74 \\
\pm 1.70\end{array}$ & $\begin{array}{l}18.07 \\
\pm 1.83\end{array}$ & 58 & 0.25 & $\begin{array}{l}15.00 \\
\pm 2.69\end{array}$ & $\begin{array}{l}15.60 \\
\pm 2.11\end{array}$ & 21 & 0.56 & $\begin{array}{l}16.65 \\
\pm 1.99\end{array}$ & $\begin{array}{l}21.16 \\
\pm 2.95\end{array}$ & 10 & 0.31 \\
\hline $\begin{array}{l}\text { Standing litter } \\
\text { height }(\mathrm{cm})\end{array}$ & $\begin{array}{c}9.51 \\
\pm 1.88\end{array}$ & $\begin{array}{l}10.40 \\
\pm 1.88\end{array}$ & 63 & 0.35 & $\begin{array}{c}9.51 \\
\pm 2.69\end{array}$ & $\begin{array}{l}12.29 \\
\pm 2.90\end{array}$ & 15 & 0.23 & $\begin{array}{l}9.52 \\
\pm 2.79\end{array}$ & $\begin{array}{l}8.04 \\
\pm 2.07\end{array}$ & 18 & 1.06 \\
\hline Litter cover $(\%)$ & $\begin{array}{l}64.45 \\
\pm 3.29\end{array}$ & $\begin{array}{l}61.16 \\
\pm 3.81\end{array}$ & 114 & 0.23 & $\begin{array}{l}63.45 \\
\pm 5.48\end{array}$ & $\begin{array}{l}61.75 \\
\pm 5.32\end{array}$ & 33 & 0.62 & $\begin{array}{l}65.71 \\
\pm 3.23\end{array}$ & $\begin{array}{l}60.42 \\
\pm 5.81\end{array}$ & 28 & 0.20 \\
\hline $\begin{array}{l}\text { Bare ground } \\
\text { cover }(\%)\end{array}$ & $\begin{array}{l}13.13 \\
\pm 1.62\end{array}$ & $\begin{array}{l}16.06 \\
\pm 2.47\end{array}$ & 66 & 0.42 & $\begin{array}{l}11.84 \\
\pm 2.01\end{array}$ & $\begin{array}{l}16.69 \\
\pm 3.76\end{array}$ & 13 & 0.16 & $\begin{array}{l}14.75 \\
\pm 2.68\end{array}$ & $\begin{array}{l}15.28 \\
\pm 3.22\end{array}$ & 22 & 0.64 \\
\hline $\begin{array}{l}\text { Biocrust cover } \\
(\%)\end{array}$ & $\begin{array}{l}14.70 \\
\pm 1.95\end{array}$ & $\begin{array}{l}17.70 \\
\pm 2.73\end{array}$ & 74 & 0.64 & $\begin{array}{l}15.39 \\
\pm 2.77\end{array}$ & $\begin{array}{l}16.14 \\
\pm 2.59\end{array}$ & 30 & 0.85 & $\begin{array}{l}13.85 \\
\pm 2.87\end{array}$ & $\begin{array}{l}19.65 \\
\pm 5.38\end{array}$ & 11 & 0.38 \\
\hline
\end{tabular}

All statistical analyses were conducted in $\mathrm{R}$ version 2.15 using the packages AICcmodavg for calculation of $\mathrm{AIC}_{\mathrm{c}}$, and exactRankTests for paired Wilcoxon signed rank tests ( $\mathrm{R}$ Core Team 2012, Hothorn and Hornik 2013, Mazerolle 2013). Code for the specialized link function used in the logistic exposure method was obtained from the U.S. Geological Survey Northern Prairie Research Center (M. Herzog, http://www.npwrc.usgs.gov/ resource/birds/nestsurv/download/CreateLogisticExposureFamily. $\mathrm{R})$.

\section{RESULTS}

\section{Nest abundance}

Seventy five nests were found and monitored (Table 5). Overall, fewer nests were found per plot in edge habitat than in interior habitat $\left(\mathrm{U}_{18}=20, P=0.01\right.$; Fig. $\left.2 \mathrm{~A}\right)$. When agricultural types were considered separately, there were far fewer nests found in orchard edge habitat than the paired interior habitat $\left(\mathrm{U}_{9}=6, P\right.$ $=0.07)$. Vineyard edge habitat did not have significantly fewer nests than paired interior habitat $\left(\mathrm{U}_{7}=5.5, P=0.17\right.$; but see Fig. 2A). This lack of edge effect was in part due to the presence of a vineyard edge outlier where there were multiple Lark Sparrows, whose nests are easier to find. After removal of this outlier, there were significantly fewer nests in vineyard edge habitat than in vineyard interior habitat $\left(\mathrm{U}_{6}=0, P=0.03\right)$.

Overall, there were fewer per capita nests in edge habitat than interior habitat $\left(\mathrm{U}_{17}=28, P=0.02\right.$; Fig. 2B). Among agricultural types, vineyard edge habitat had fewer per capita nests than the respective paired interior habitat $\left(\mathrm{U}_{7}=4, P=0.05\right)$. Orchard edge and paired interior habitat had similar per capita abundances of nests $\left(\mathrm{U}_{9}=9, P=0.13\right)$.

\section{Nest predator detection}

Ten of the 35 nests monitored with cameras were depredated. We identified predators in eight predation events at seven of these nests (one nest was partially depredated twice by two different snake species; Table 6). We observed two additional predation events at nests where cameras were not deployed. Two species of snake, two species of birds, and two species of mammal were identified as nest predators. Snakes, particularly yellow-bellied racers, were the most common predator of songbird nests in sagebrush shrubsteppe.

\section{Nest predator abundance}

The abundance of large mammal predators, bird predators, and mice was similar in edge and interior habitat (Table 7). There were more snakes in edge than interior habitat. When we analyzed individual predator species, we found yellow-bellied racers were more abundant in orchard edge habitat, and vineyard edge habitat than the corresponding interior habitats. In contrast, the abundance of gopher snakes was similar between all habitat types. The abundance of Black-billed magpies and Western Meadowlarks in edge and interior habitat did not differ, although there was a suggestion that Black-billed magpies were less abundant in orchard edge habitat than orchard interior plots. 
Fig. 2. A. Difference in the number of songbird nests found in edge and interior sagebrush habitat. Difference in the number of nests was calculated as the number of nests in each edge plot minus the number of nests in the paired interior plot. B. Difference in the number of per capita songbird nests found in edge and interior sagebrush habitat. Difference in per capita nests was calculated as the mean nests per songbird in each edge plot minus the mean nests per songbird in the paired interior plot. Edge habitat was located adjacent to vineyard (n $=8)$ or orchard $(\mathrm{n}=10)$. All sites includes orchard and vineyard sites pooled. Box ends represent the 25 th and 75 th percentiles, whiskers represent 1.5 interquartile range, and dots represent outliers in all boxplots.

A
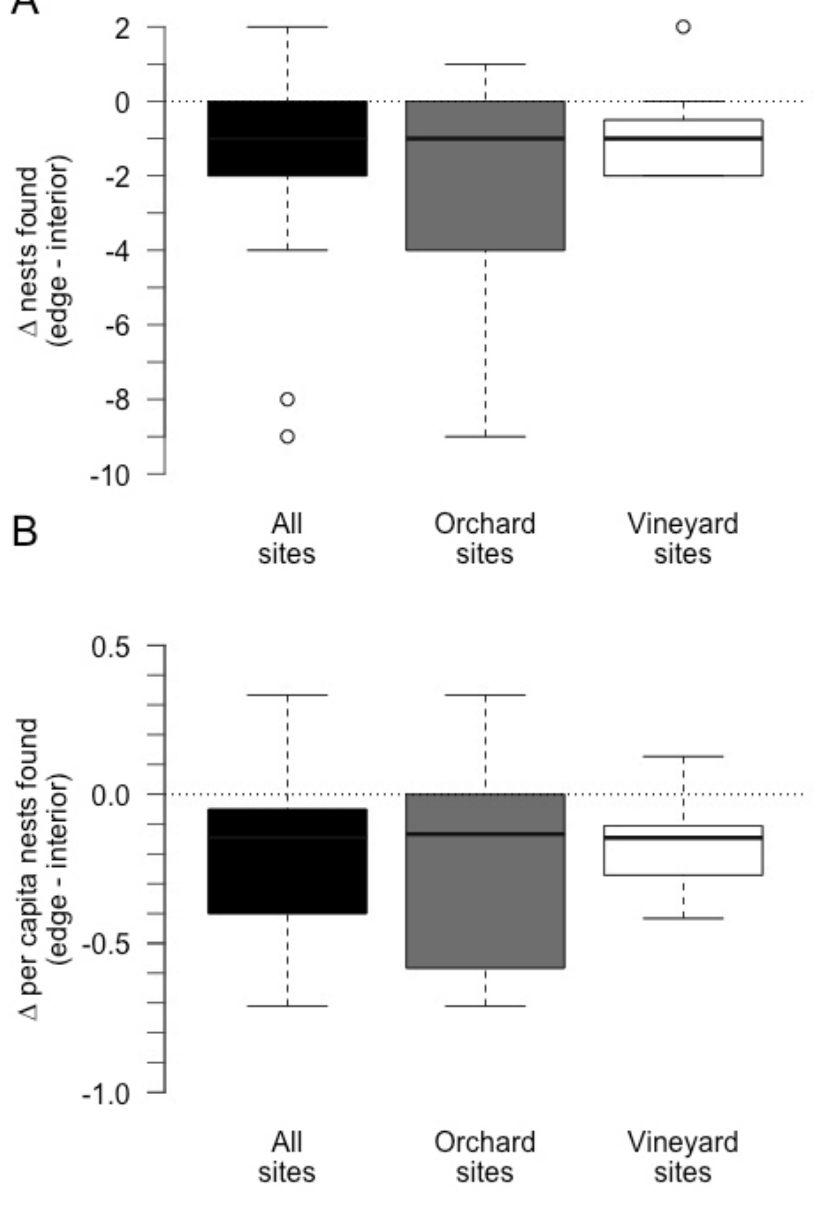

\section{Vegetation}

Grass height, native forb cover, standing litter height, litter cover, bare ground cover, and biocrust cover were similar between all habitat types (all $P>0.05$; Table 2). Orchard edge habitat had higher shrub cover, higher exotic grass cover, and lower native grass cover than interior habitat, although the difference in shrub cover was marginal. Local vegetation in vineyard edge habitat was similar to local vegetation in vineyard interior habitat, with the exception of shrub height, which was greater in both types of agricultural edge habitat than interior habitat.
Table 3. $\mathrm{AIC}_{\mathrm{C}}$ ranking of logistic-exposure models for predationspecific daily nest survival rate of songbirds nesting in sagebrush habitat. A multistep variable inclusions approach was used to minimize the number of variables in any given model. The top three models for each step are shown. See Table 1 for terms.

\begin{tabular}{lrrrrr}
\hline \hline Model & $N$ & $K$ & $\mathrm{AIC}_{\mathrm{C}}$ & $\Delta \mathrm{AIC}_{\mathrm{C}}$ & $w_{i}$ \\
\hline Step 1. Species effects (8 models) & & & & \\
Fate = Null & 209 & 1 & 166.82 & 0.00 & 0.42 \\
Fate $=$ Cam & 208 & 2 & 168.12 & 1.30 & 0.22 \\
Fate = Type & 208 & 2 & 168.54 & 1.72 & 0.18
\end{tabular}

Step 2. Temporal effects (12 models)

$\begin{array}{llllll}\text { Fate }=\text { Stage } & 208 & 2 & 165.92 & 0.00 & 0.19 \\ \text { Fate }=\text { Null } & 209 & 1 & 166.68 & 0.76 & 0.13 \\ \text { Fate }=\text { Stage }+ \text { Year } & 207 & 3 & 166.82 & 0.90 & 0.12\end{array}$

Step 3a. Predator effects by group (16 models)

$\begin{array}{llllll}\text { Fate }=\text { Null } & 209 & 1 & 166.82 & 0.00 & 0.19 \\ \text { Fate }=\text { Mammal } & 208 & 2 & 167.22 & 0.40 & 0.16 \\ \text { Fate }=\text { Mice } & 208 & 2 & 168.38 & 1.56 & 0.09\end{array}$

Step 3b. Predator effects by species (16 models)

$\begin{array}{llllll}\text { Fate }=\text { BBMA } & 208 & 2 & 166.00 & 0.00 & 0.17 \\ \text { Fate }=\text { BBMA }+ \text { Racer } & 207 & 3 & 166.24 & 0.25 & 0.15 \\ \text { Fate }=\text { Null } & 209 & 1 & 166.82 & 0.82 & 0.11\end{array}$

Step 4. Plot vegetation effects (16 models)

$\begin{array}{llllll}\text { Fate }=\text { Shrub } \% & 208 & 2 & 161.80 & 0.00 & 0.32 \\ \text { Fate }=\text { Shrub } \%+\text { Native } & 207 & 3 & 163.62 & 1.83 & 0.13 \\ \text { Grass } \% & & & & & \\ \text { Fate }=\text { Shrub } \%+\text { Exotic } & 207 & 3 & 163.83 & 2.03 & 0.12\end{array}$

Grass $\%$

Step 5. Nest vegetation effects (20 models)

$\begin{array}{llllll}\text { Fate }=\text { GrassHt } & 208 & 2 & 163.70 & 0.00 & 0.40 \\ \text { Fate }=\text { GrassHt }+ \text { Visibility } & 207 & 3 & 165.04 & 1.34 & 0.20 \\ \text { Fate }=\text { GrassHt }+ \text { ShrubD } & 207 & 3 & 165.75 & 2.05 & 0.14\end{array}$

Nest grass height and visibility was similar in edge and interior habitat (all $P>0.05$ ). Nests in edge habitat were marginally further from shrubs than nests in interior habitat $\left(\mathrm{U}_{63}=513.5, P=0.08\right)$.

\section{Nest predation}

Of the 75 nests found, we determined the fate of 72 . Young were fledged at 37 nests and 27 nests were depredated (Table 5). The remaining nine nests failed because of abandonment following camera placement $(n=3)$, abandonment following apparent partial predation $(\mathrm{n}=2)$, abandonment following brood parasitism $(n=1)$, failure to hatch $(n=1)$, or inclement weather $(n=2)$. Predation was therefore responsible for $75 \%$ of nest failures.

Songbird species, type of nest (ground or shrub), and the presence of a nest camera did not impact PDSR (Table 4). PDSR was lower during the incubation stage, and the nest stage model had an evidence ratio of 1.58 over the null model. Predator abundance at the group level did not influence PDSR, but when examined at 
Fig. 3. Logistic exposure estimates of predation-specific daily nest survival rates of songbirds nesting in sagebrush shrubsteppe habitat. Solid lines indicate the logistic exposure estimate and dotted lines are the $95 \% \mathrm{CI}$. Nests were monitored in three habitat types: orchard edge habitat, vineyard edge habitat, and interior habitat, however we pooled vineyard edge and interior habitat because general linear modelling in an information theoretic framework indicated there was no difference in nest fate between vineyard and interior habitat. Estimates were calculated using three different models each including a habitat type term, a nest stage term (incubation and nestling estimates averaged here) and one of: Black-billed Magpie (Pica hudsonia) abundance (A), percent shrub cover (B), and grass height at nest (C).

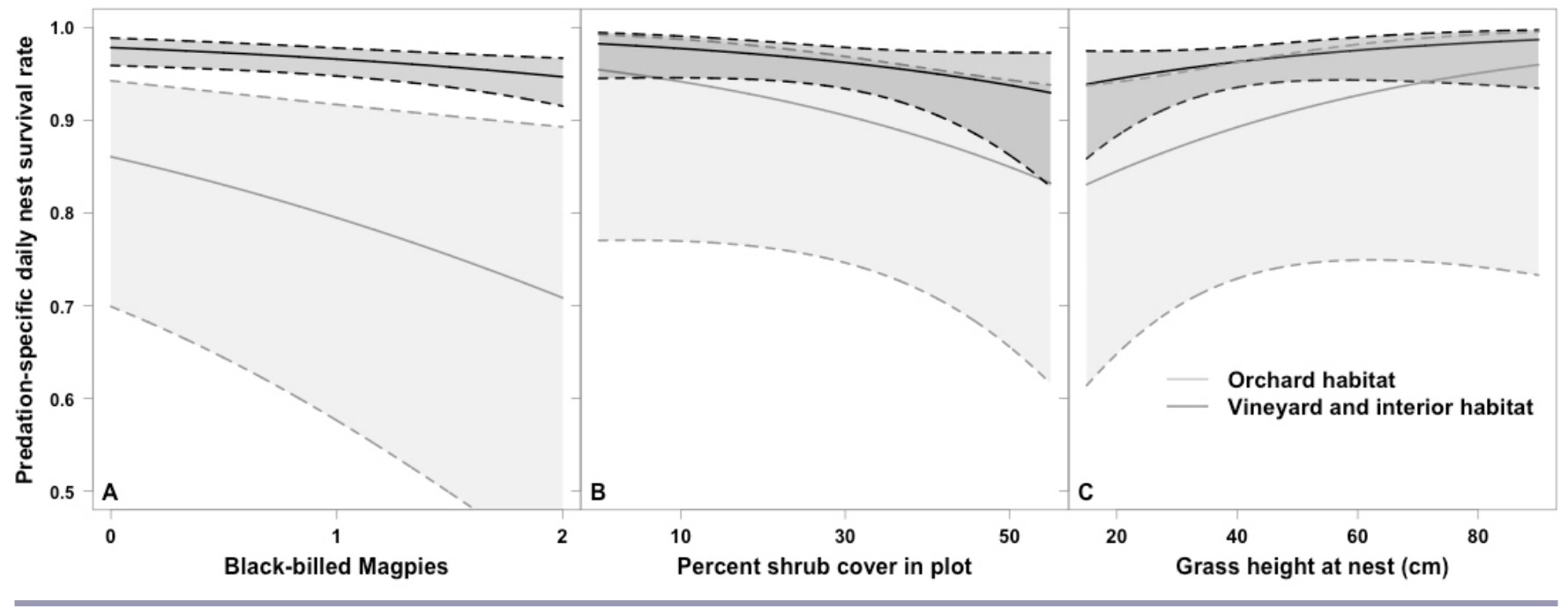

the species level, increased Black-billed Magpie abundance was associated with decreased PDSR (Figure 3), although the top

Table 4. Hypotheses developed to test for an edge effect on songbird nest predation in sagebrush shrubsteppe habitat at two different types of agricultural edges: orchard and vineyard.

\begin{tabular}{|c|c|c|}
\hline Term & Hypothesis & Levels \\
\hline$\overline{\text { Edge }}$ & $\begin{array}{l}\text { Nest fate differs between edge and interior } \\
\text { habitat }\end{array}$ & $\begin{array}{l}\text { Edge, } \\
\text { Interior }\end{array}$ \\
\hline Orchard & $\begin{array}{l}\text { Nest fate does not differ between vineyard } \\
\text { edge and interior habitat, but does differ in } \\
\text { orchard edge habitat }\end{array}$ & $\begin{array}{l}\text { Orchard } \\
\text { Edge, } \\
\text { Vineyard/ } \\
\text { Interior }\end{array}$ \\
\hline Vineyard & $\begin{array}{l}\text { Nest fate does not differ between orchard } \\
\text { edge and interior habitat, but does differ in } \\
\text { vineyard edge habitat }\end{array}$ & $\begin{array}{l}\text { Vineyard } \\
\text { Edge, } \\
\text { Orchard/ } \\
\text { Interior }\end{array}$ \\
\hline Null & $\begin{array}{l}\text { Nest fate does not differ between orchard } \\
\text { edge, vineyard edge, and interior habitat }\end{array}$ & None \\
\hline
\end{tabular}

model including Black-billed Magpie abundance only had an evidence ratio of 1.54 over the null model. Among vegetation characteristics at the plot level, the percent cover of shrubs was present in the top seven models, and was a strong negative predictor of PDSR with an evidence ratio of 10.66 over the null model. At the nest site, grass height was present in the top four models, and was a strong positive predictor of PDSR with an evidence ratio of 5.00 .

We found evidence for edge effects on PDSR in one agricultural edge habitat type. There was strong support for the model representing a difference in PDSR in orchard edge habitat, with an evidence ratio of 4.6 over the null model. The other models representing a vineyard edge effect and general edge effect hypothesis had less support than the null model (Table 8). Despite the small number of nests in the orchard edge habitat, bootstrapped estimates of PDSR calculated by resampling from our sample of nests within each habitat had confidence intervals with minimal overlap (orchard edge PDSR $=$ CI etc. The set of bootstrapped data fitted to the orchard edge hypothesis model estimated PDSR was $0.860(0.685-0.94695 \% \mathrm{CI})$ in orchard edge habitat and $0.966(0.941-0.98195 \% \mathrm{CI})$ in interior and vineyard habitat (Fig. 3A).

After inclusion of the mechanism variables to the null and orchard models, the orchard edge term was included in four of the top five models, and had a summed $w_{i}$ of 0.74 . Vegetation differences at the study plot or nest site therefore do not completely explain the orchard edge effect on PDSR. Nevertheless our analysis provides some evidence that shrub cover within the study plot explains some of the orchard effect because the model including orchard and shrub cover had only slightly more support than the model including shrub cover alone (evidence ratio $=1.14, \Delta \mathrm{IC}_{\mathrm{C}}$ $=0.32$; Table 8). Increasing shrub cover was associated with a decrease in PDSR (Fig. 3B). Similarly, we found some evidence that grass height at the nest site explains some of the orchard effect because the model including orchard and grass height at the nest site had only slightly more support than the model with grass height alone (evidence ratio $=1.50, \Delta \mathrm{IC}_{\mathrm{C}}=0.93$ ). Increasing nest site grass height was associated with an increase in PDSR (Fig. 3C). A post-hoc Wilcoxon rank sum test showed that nest grass height is marginally lower at nests in orchard edge habitat than at nests in vineyard or interior habitat $\left(\mathrm{U}_{63}=278.5, P=\right.$ 
Table 5. Numbers of songbirds detected, songbird nests found (including fate), and nest predator identifications in three types of sagebrush habitat. Songbird species studied were Brewer's Sparrows, Spizella breweri (BRSP), Lark Sparrows, Chondestes grammacus (LASP), Vesper Sparrows, Pooecetes gramineus (VESP), and Western Meadowlarks, Sturnella neglecta (WEME).

\begin{tabular}{|c|c|c|c|c|c|c|}
\hline \multirow[t]{2}{*}{ Variable measured } & \multicolumn{2}{|c|}{$\begin{array}{l}\text { Orchard edge habitat } \\
\qquad(\mathrm{n}=10)\end{array}$} & \multicolumn{2}{|c|}{$\begin{array}{l}\text { Vineyard edge habitat } \\
(\mathrm{n}=8)\end{array}$} & \multicolumn{2}{|c|}{$\begin{array}{l}\text { Interior habitat } \\
(\mathrm{n}=18)\end{array}$} \\
\hline & Mean \pm se & Total & Mean \pm se & Total & Mean \pm se & Total \\
\hline \multicolumn{7}{|c|}{ Maximum number of birds detected on a single point count } \\
\hline BRSP & $0.60 \pm 0.31$ & 6 & $0.12 \pm 0.12$ & 1 & $1.22 \pm 0.46$ & 22 \\
\hline LASP & $0.80 \pm 0.20$ & 8 & $1.34 \pm 0.18$ & 11 & $0.61 \pm 0.20$ & 11 \\
\hline VESP & $1.20 \pm 0.25$ & 12 & $2.62 \pm 0.42$ & 21 & $3.17 \pm 0.32$ & 57 \\
\hline WEME & $1.60 \pm 0.45$ & 16 & $2.40 \pm 0.65$ & 19 & $2.17 \pm 0.53$ & 39 \\
\hline Total & $4.20 \pm 0.73$ & 42 & $6.50 \pm 0.87$ & 52 & $7.17 \pm 0.58$ & 129 \\
\hline \multicolumn{7}{|l|}{ Nests found } \\
\hline BRSP & $0.10 \pm 0.10$ & 1 & $0.00 \pm 0.00$ & 0 & $0.78 \pm 0.50$ & 14 \\
\hline LASP & $0.50 \pm 0.22$ & 5 & $0.50 \pm 0.38$ & 4 & $0.44 \pm 0.29$ & 8 \\
\hline VESP & $0.20 \pm 0.20$ & 2 & $0.62 \pm 0.26$ & 5 & $1.56 \pm 0.32$ & 28 \\
\hline WEME & $0.10 \pm 0.10$ & 1 & $0.50 \pm 0.27$ & 4 & $0.17 \pm 0.38$ & 3 \\
\hline Total & $0.90 \pm 0.28$ & 9 & $1.62 \pm 0.60$ & 13 & $2.94 \pm 0.70$ & 53 \\
\hline Fate unknown & & 1 & & 0 & & 2 \\
\hline Abandoned & & 1 & & 0 & & 5 \\
\hline Failed because of weather & & 0 & & 0 & & 2 \\
\hline Predated & & 5 & & 4 & & 18 \\
\hline Fledged & & 2 & & 9 & & 26 \\
\hline \multicolumn{7}{|c|}{ Nest predator identification sample sizes } \\
\hline Nest cameras deployed & & 4 & & 7 & & 24 \\
\hline Predator identifications & & 2 & & 3 & & 5 \\
\hline
\end{tabular}

0.09). There was little relationship between study plot shrub cover and nest grass height in post-hoc Pearson's test for correlation ( $\mathrm{r}$ $=-0.22, \mathrm{n}=61, \mathrm{p}=0.02)$, suggesting these two vegetation characteristics each explain different portions of the observed orchard edge effect on nest predation.

Overall, PDSR was best described by the orchard edge hypothesis, nest stage, and the abundance of Black-billed Magpies, and the orchard edge hypothesis term (Table 8 ). This top model estimated overall PDSR as $0.958(0.915-0.98095 \% \mathrm{CI})$.

\section{DISCUSSION}

Fragmentation of sagebrush landscapes has been suggested to contribute to observed declines of songbirds in sagebrush habitat (Knick and Rotenberry 2002, Knick et al. 2003, Vander Haegen 2007). Songbirds in fragmented sagebrush landscapes experience higher rates of nest predation and modeling suggests this contributes to negative population growth in fragmented landscapes (Vander Haegen et al. 2002, Vander Haegen 2007). Several authors have suggested these types of fragmentation effects detected at large scales are caused by the cumulative impact of edge effects across the landscape (Bender et al. 1998, Ries et al. 2004, Fletcher et al. 2007). We showed here that there are multiple reproductive edge effects on songbirds breeding in sagebrush habitat. There was a reduction in the number of overall nesting attempts and nesting attempts per songbird in agricultural edge habitat than interior sagebrush habitat. We also found increased predation rates in sagebrush habitat adjacent to orchards partially because of differences in vegetation.

Our study finds that songbirds in sagebrush edge habitat suffer reproductive impacts that are not detected with abundance estimates, and supports previous reports of sagebrush edge avoidance (Ingelfinger and Anderson 2004). We found fewer total nest attempts in both types of agricultural edge habitat than their respective interior habitat. When we compared per capita nesting attempts, however, we only detected a difference between paired vineyard edge and interior habitats, suggesting that the edge effects on nest abundance differ between the two edge types we studied. The edge effect on nest abundance in orchard edge habitat appears to be due to edge avoidance: individuals, particularly Vesper and Brewer's Sparrows, do not occupy orchard edge habitat as frequently as interior habitat, and so the relative abundance of nests found in orchard edge habitat is also lower. Grassland songbirds have varied responses to the presence of edges (Helzer and Jelinski 1999, Ribic et al. 2009), but birds in sagebrush shrubsteppe generally show sensitivity to habitat fragmentation (Knick and Rotenberry 1995, Ingelfinger and Anderson 2004, Vander Haegen 2007). Songbirds likely avoid edges with stronger vegetative contrast, and songbirds in sagebrush habitat in the study region have previously been shown to avoid areas with high tree density (Krannitz 2007). We suggest 
Table 6. Details of confirmed predation events at songbird nests in sagebrush habitat. Predation events were considered confirmed if recorded by nest camera or visually observed.

\begin{tabular}{lccccc}
\hline \hline Predator species & Observation type & Date & Time & Songbird species & Study habitat type \\
\hline $\begin{array}{l}\text { Domestic cow } \\
\begin{array}{l}\text { Bos primigenius) } \\
\text { Unidentified mammal }\end{array}\end{array}$ & Camera & $2012-07-29$ & $19: 10$ & $\begin{array}{c}\text { Vesper Sparrow } \\
\text { (Pooecetes gramineus) } \\
\text { Lark Sparrow } \\
\text { (Chondestes }\end{array}$ & Interior \\
grammacus)
\end{tabular}

Mammal total: 2

\begin{tabular}{|c|c|c|c|c|c|}
\hline $\begin{array}{l}\text { Black-billed Magpie } \\
\text { (Pica hudsonia) }\end{array}$ & Camera & 2012-06-12 & $09: 33$ & Vesper Sparrow & Interior \\
\hline $\begin{array}{l}\text { Western Meadowlark (Sturnella } \\
\text { neglecta) }\end{array}$ & Camera & 2012-06-09 & $10: 13$ & Lark Sparrow & Vineyard edge \\
\hline $\begin{array}{l}\text { Western Meadowlark } \\
\text { Bird total: } 3\end{array}$ & Visual & 2012-05-29 & $07: 43$ & Vesper Sparrow & Interior \\
\hline $\begin{array}{l}\text { Yellow-bellied racer } \\
\text { (Coluber constrictor) }\end{array}$ & Camera & 2011-07-03 & $10: 05$ & Vesper Sparrow & Interior \\
\hline Yellow-bellied racer & Camera & 2011-06-19 & 20:01 & Vesper Sparrow & Interior \\
\hline Yellow-bellied racer & Camera & 2011-06-29 & $11: 23$ & Vesper Sparrow & Vineyard edge \\
\hline Yellow-bellied racer & Visual & 2011-06-04 & $08: 23$ & $\begin{array}{l}\text { Brewer's Sparrow } \\
\text { (Spizella breweri) }\end{array}$ & Orchard edge \\
\hline $\begin{array}{l}\text { Gopher snake } \\
\text { (Pituophis catenfir) } \\
\text { Snake total: } 5\end{array}$ & Camera & 2011-06-27 & $16: 48$ & Vesper Sparrow & Vineyard edge \\
\hline
\end{tabular}

songbirds in sagebrush habitat avoid treed orchard edges, but not more shrub-like vineyard edges. Alternatively, the edge effect on nest abundance in vineyard edge habitat could be due to reduced observer ability to find nests or fewer per capita nesting attempts. Although we did choose paired plots with similar vegetation, there was slightly higher native bunchgrass cover in vineyard edge habitat, but we do not believe this was enough to reduce the number of nests found. Instead, we suggest a vineyard edge effect on per capita nest attempts is due to reduced pairing success. We recorded multiple male Vesper Sparrows, the most common bird in our study sites, whose territories included vineyard habitat and who did not appear to attract mates. Ovenbirds (Seiurus aurocapilla) that reside closer to forest edges also have reduced pairing success perhaps because of an abundance of first-time breeders in edge habitat (Van Horn et al. 1995, Bayne and Hobson 2001). In combination, the reduced total nest abundance in orchard edge habitat and reduced per capita nest abundance in vineyard edge habitat detected in this study suggest sagebrush habitat adjacent to agriculture is of poor quality for songbirds.

Edge effects on nest predation are most often attributed to higher nest predator abundance in edge habitat, such as the higher predation rate we detected in orchard edge, but not vineyard edge habitat (Chalfoun et al. 2002, Smith 2004). Contrary to expectation, nest predator abundance did not explain the edge effect on nest predation in orchard edge habitat here. Snakes, the dominant nest predators, were found most frequently in vineyard edge habitat, whereas orchard edge habitat had the highest nest predation rate. This discrepancy between snake abundance and nest predation rates suggests snakes use vineyard edge habitat for activities other than foraging. Two similar studies also concluded that snakes were not foraging in edge habitat where they were most abundant because they did not cause higher predation rates of songbird nests (Sperry et al. 2009, Weatherhead et al. 2010). There is anecdotal evidence that snakes in this region are traveling through vineyard edge habitat to the adjacent vineyards because they are attracted to high rodent abundance and irrigated areas (C. Bishop, personal communication), while snakes are likely residing and foraging in orchard edge habitat. Increased abundance of another known predator, the Black-billed Magpie, did decrease daily nest survival, but did not explain the edge effect on nest predation because Black-billed Magpies were more abundant in interior than orchard edge habitat.

Another possible explanation for an edge effect on nest predation is differences in vegetation that make it easier for predators to locate nests in edge habitat (Smith 2004). We found that lower grass height at the nest and increased shrub cover in the study plot both explained portions of the edge effect on nest predation observed at orchard edges. Grassland songbirds often pick nest sites with taller grass, likely because higher vegetation conceals nests better (Davis 2005). This concealment theory is supported by many studies finding a relationship between grass height at the nest and nest survival (Davis 2005, Klug et al. 2010, Stauffer et al. 2011). The predators detected by nest cameras here, particularly snakes, Black-billed Magpies, and Western Meadowlarks, are visual predators that could benefit increased foraging efficiency from reduced nest concealment (Weatherhead 
Table 7. The relative abundance of potential predators of songbird nests in edge and interior sagebrush habitat. Predators were analyzed by major taxonomical group and as individual species. Edge habitat was located adjacent to vineyard $(\mathrm{n}=8)$ or orchard $(\mathrm{n}=10)$. All sites includes orchard and vineyard sites pooled. Differences between edge and interior sites were tested with paired Wilcoxon rank sign tests.

\begin{tabular}{|c|c|c|c|c|c|c|c|c|c|c|c|c|}
\hline \multirow[b]{2}{*}{ Predator } & \multicolumn{4}{|c|}{ All sites } & \multicolumn{4}{|c|}{ Orchard sites } & \multicolumn{4}{|c|}{ Vineyard sites } \\
\hline & $\begin{array}{c}\text { Edge } \\
\text { habitat } \\
\text { mean } \\
\pm \text { se }\end{array}$ & $\begin{array}{c}\text { Interior } \\
\text { habitat } \\
\text { mean } \\
\pm \mathrm{se}\end{array}$ & $\mathrm{U}$ & $P$ & $\begin{array}{c}\text { Edge } \\
\text { habitat } \\
\text { mean } \pm \\
\text { se }\end{array}$ & $\begin{array}{c}\text { Interior } \\
\text { habitat } \\
\text { mean } \pm \\
\text { se }\end{array}$ & $\mathrm{U}$ & $P$ & $\begin{array}{c}\text { Edge } \\
\text { habitat } \\
\text { mean } \pm \\
\text { se }\end{array}$ & $\begin{array}{c}\text { Interior } \\
\text { habitat } \\
\text { mean } \pm \\
\text { se }\end{array}$ & $\mathrm{U}$ & $P$ \\
\hline \multicolumn{13}{|l|}{ Predator group } \\
\hline Birds & $\begin{array}{l}3.72 \\
\pm 0.54\end{array}$ & $\begin{array}{l}3.50 \\
\pm 0.73\end{array}$ & 75.5 & 0.72 & $\begin{array}{l}3.20 \\
\pm 0.51\end{array}$ & $\begin{array}{l}2.70 \\
\pm 0.97\end{array}$ & 29 & 0.51 & $\begin{array}{l}4.38 \\
\pm 1.03\end{array}$ & $\begin{array}{l}4.50 \\
\pm 1.07\end{array}$ & 13 & 0.94 \\
\hline $\begin{array}{l}\text { Large mammal } \\
\text { species }\end{array}$ & $\begin{array}{l}2.11 \\
\pm 0.24\end{array}$ & $\begin{array}{l}1.83 \\
\pm 0.25\end{array}$ & 60.5 & 0.31 & $\begin{array}{l}2.20 \\
\pm 0.36\end{array}$ & $\begin{array}{l}1.70 \\
\pm 0.26\end{array}$ & 22 & 0.19 & $\begin{array}{l}2.00 \\
\pm 0.33\end{array}$ & $\begin{array}{l}2.00 \\
\pm 0.46\end{array}$ & 10.5 & 1.19 \\
\hline Mice & $\begin{array}{c}0.31 \\
\pm 0.07\end{array}$ & $\begin{array}{l}0.27 \\
\pm 0.07\end{array}$ & 89 & 0.58 & $\begin{array}{c}0.31 \\
\pm 0.07\end{array}$ & $\begin{array}{c}0.31 \\
\pm 0.10\end{array}$ & 26 & 0.92 & $\begin{array}{c}0.31 \\
\pm 0.13\end{array}$ & $\begin{array}{l}0.23 \\
\pm 0.09\end{array}$ & 20 & 0.38 \\
\hline Snakes & $\begin{array}{c}0.10 \\
\pm 0.02\end{array}$ & $\begin{array}{c}0.05 \\
\pm 0.01\end{array}$ & 141 & $<0.001$ & $\begin{array}{c}0.08 \\
\pm 0.02\end{array}$ & $\begin{array}{c}0.05 \\
\pm 0.01\end{array}$ & 38 & 0.07 & $\begin{array}{c}0.13 \\
\pm 0.03\end{array}$ & $\begin{array}{c}0.05 \\
\pm 0.02\end{array}$ & 36 & 0.01 \\
\hline \multicolumn{13}{|l|}{ Predator species } \\
\hline $\begin{array}{l}\text { Black-billed } \\
\text { Magpie (Pica } \\
\text { hudsonia) }\end{array}$ & $\begin{array}{c}0.39 \\
\pm 0.14\end{array}$ & $\begin{array}{c}0.89 \\
\pm 0.24\end{array}$ & 11.5 & 0.12 & $\begin{array}{c}0.20 \\
\pm 0.13\end{array}$ & $\begin{array}{c}1.10 \\
\pm 0.38\end{array}$ & 0 & 0.06 & $\begin{array}{c}0.62 \\
\pm 0.26\end{array}$ & $\begin{array}{c}0.62 \\
\pm 0.26\end{array}$ & 7.5 & 1.25 \\
\hline $\begin{array}{l}\text { Gopher snake } \\
\text { (Pituophis } \\
\text { catenfir) }\end{array}$ & $\begin{array}{c}0.02 \\
\pm 0.01\end{array}$ & $\begin{array}{c}0.02 \\
\pm 0.01\end{array}$ & 41 & 0.79 & $\begin{array}{c}0.01 \\
\pm 0.01\end{array}$ & $\begin{array}{c}0.02 \\
\pm 0.01\end{array}$ & 4 & 0.22 & $\begin{array}{c}0.03 \\
\pm 0.01\end{array}$ & $\begin{array}{c}0.02 \\
\pm 0.01\end{array}$ & 18 & 0.58 \\
\hline $\begin{array}{l}\text { Western } \\
\text { Meadowlark } \\
\text { (Sturnella } \\
\text { neglecta) }\end{array}$ & $\begin{array}{c}1.94 \\
\pm 0.38\end{array}$ & $\begin{array}{c}2.17 \\
\pm 0.53\end{array}$ & 32.5 & 0.63 & $\begin{array}{c}1.60 \\
\pm 0.45\end{array}$ & $\begin{array}{c}1.50 \\
\pm 0.62\end{array}$ & 8.5 & 1.00 & $\begin{array}{c}2.38 \\
\pm 0.65\end{array}$ & $\begin{array}{c}3.00 \\
\pm 0.87\end{array}$ & 9.5 & 0.55 \\
\hline $\begin{array}{l}\text { Yellow-bellied } \\
\text { racer (Coluber } \\
\text { constrictor) }\end{array}$ & $\begin{array}{c}0.09 \\
\pm 0.01\end{array}$ & $\begin{array}{c}0.03 \\
\pm 0.01\end{array}$ & 153 & $<0.001$ & $\begin{array}{c}0.07 \\
\pm 0.02\end{array}$ & $\begin{array}{c}0.03 \\
\pm 0.01\end{array}$ & 45 & 0.003 & $\begin{array}{c}0.10 \\
\pm 0.02\end{array}$ & $\begin{array}{c}0.03 \\
\pm 0.02\end{array}$ & 36 & 0.01 \\
\hline
\end{tabular}

and Blouin Demers 2004, Davis and Lanyon 2008, Birkhead 2010). A negative relationship between shrub cover and nest survival has also been detected for grassland songbirds, and is thought to occur because shrubs provide cover or habitat for nest predators (With 1994). In particular, nest predation risk by snakes is higher in areas with more shrubs because the snakes likely use shrubs for thermoregulation (Klug et al. 2010). We suggest orchard edge habitat in the Okanagan is characterized by high predation rates because of an interaction between snake behavior and high shrub cover, but we were unable to test for this interaction because of our small orchard edge sample size. We are unsure why shrub cover is particularly high in orchard edge habitat, but suggest it could result from deeper soils near agricultural areas (Vander Haegen et al. 2000, Iverson et al. 2008). Regardless, further investigation is required to elucidate whether the vegetation effects on nest predation detected here can be generalized to all orchard edge habitat in the study region. The only previous edge effect on nest predation study in sagebrush shrubsteppe habitat did not find higher nest predation adjacent to agriculture (Vander Haegen et al. 2002), but their study addressed a different crop type.

We remain confident in our conclusion that nest predation rates are higher in orchard edge habitat despite relatively small sample sizes, particularly in orchard edge habitat. Although the sample sizes are small, they were adequate to detect other biologically relevant impacts, such as variation in nest predation rates with nest stage (e.g., Renfrew and Ribic 2003). Our sample sizes were also large enough to detect vegetation and predator effects on nest predation rate. Despite accounting for all of these potential factors, our information theoretic approach still finds support for an edge effect on nest predation. We have also analyzed the data in multiple ways, and remain confident the nest survival data are indicative of a real trend in orchard edge habitat.

Similarity between the daily nest survival rate found here and daily nest survival rates of songbirds in sagebrush habitat calculated in other fragmented landscapes with negative population growth (Vander Haegen 2007) suggests that reproduction in the Okanagan area is insufficient to maintain songbird populations in sagebrush habitat. Negative population trends have been detected in the study region for all four songbird species studied here, and edge effects on reproduction may be contributing to these declines (Sauer et al. 2014). We recommend several management steps that can be taken to mitigate edge effects on songbird reproduction in sagebrush habitat. First, conservation areas for songbirds in Okanagan sagebrush habitat should be placed away from agricultural areas to avoid negative 
Table 8. $\mathrm{AIC}_{\mathrm{C}}$ ranking of logistic-exposure models for predation-specific daily nest survival rate of songbirds nesting in sagebrush habitat. Four specific edge-effect hypotheses were initially tested (see Table 3), and then potential explanatory mechanism variables were added for final model selection. All models tested are shown. See Table 1 for terms.

\begin{tabular}{|c|c|c|c|c|c|}
\hline Model & $N$ & $K$ & $\mathrm{AIC}_{\mathrm{C}}$ & $\Delta \mathrm{AIC}_{\mathrm{C}}$ & $w_{i}$ \\
\hline \multicolumn{6}{|l|}{ Edge effect hypotheses } \\
\hline Fate $=$ Orchard + Stage & 207 & 3 & 162.61 & 0.00 & 0.72 \\
\hline Fate $=$ Stage & 208 & 2 & 165.92 & 3.31 & 0.14 \\
\hline Fate $=$ Vineyard + Stage & 207 & 3 & 167.25 & 4.64 & 0.07 \\
\hline Fate $=$ Edge + Stage & 207 & 3 & 167.31 & 4.70 & 0.07 \\
\hline \multicolumn{6}{|l|}{ Final model selection } \\
\hline Fate $=$ Orchard + BBMA + Stage & 206 & 4 & 159.05 & 0.00 & 0.36 \\
\hline Fate $=$ Orchard + BBMA + GrassHt + Shrub $\%+$ Stage & 204 & 6 & 159.74 & 0.70 & 0.25 \\
\hline Fate $=$ BBMA + GrassHt + Shrub $\%+$ Stage & 205 & 5 & 160.91 & 1.86 & 0.14 \\
\hline Fate $=$ Orchard + GrassHt + Stage & 206 & 4 & 162.24 & 3.19 & 0.07 \\
\hline Fate $=$ Orchard + Shrub $\%+$ Stage & 206 & 4 & 162.60 & 3.56 & 0.06 \\
\hline Fate $=$ Shrub $\%+$ Stage & 207 & 3 & 162.60 & 3.56 & 0.06 \\
\hline Fate $=$ GrassHt + Stage & 207 & 3 & 164.00 & 4.96 & 0.03 \\
\hline Fate $=$ BBMA + Stage & 207 & 3 & 165.12 & 6.07 & 0.02 \\
\hline
\end{tabular}

reproductive impacts of habitat edges on songbirds in sagebrush habitat. To prevent edge avoidance and potentially higher nest predation rates in orchard edge habitat, managers should avoid the creation of new orchard-sagebrush habitat edges or buffer orchard edges and encourage the presence of vineyards at the periphery of the agricultural matrix. In light of the different edge effects adjacent to different crop types detected here, we discourage future agricultural edge effect studies from grouping agricultural edge types together. If crop types are not separated, edge effects may not be detected, or the results may be unnecessarily generalized and ineffective management taken.

Responses to this article can be read online at:

http://www.ace-eco.org/issues/responses.php/662

\footnotetext{
Acknowledgments:

Thank you to three anonymous reviewers whose detailed comments greatly improved the first version of this manuscript, and to Dr. Elizabeth Elle who provided comments to the thesis version of the manuscript. This research could not have been conducted without the dedicated assistance of field technicians Gregory Rickbeil, Sonia Nicholl, Hannah Gehrels, Megan McAndrew, and Sebastián Pardo. Funding and equipment for this project was provided by Environment Canada, the Centre for Wildlife Ecology, the Natural Sciences and Engineering Research Council, the Nature Trust, Bushnell, and Simon Fraser University. Thank you to the staff of The Land Conservancy, the Environmental Farm Plan, the South OkanaganSimilkameen Conservation Program, and the Washington Department of Fish and Wildlife for invaluable landowner contact assistance. We sincerely thank the many private landowners who graciously granted us access to their land to conduct this research.
}

\section{LITERATURE CITED}

Andrén, H. 1995. Effects of landscape composition on predation rates at habitat edges. Pages 225-255 in L. Hansson, L. Fahrig, and G. Merriam, editors. Mosaic landscapes and ecological processes. Chapman \& Hall, London, UK.

Andrén, H., P. Angelstam, E. Lindström, and P. Widén. 1985. Differences in predation pressure in relation to habitat fragmentation: an experiment. Oikos 45:273-277. http://dx.doi. org/10.2307/3565714

Baepler, D. H. 1968. Lark sparrow. Pages 886-902 in O. L. Austin, editor. Life histories of North American cardinals, grosbeaks, buntings, towhees, finches, sparrows, and allies. Bulletin of the United States National Museum, Washington, D.C., USA.

Batáry, P., and A. Báldi. 2004. Evidence of an edge effect on avian nest success. Conservation Biology 18:389-400. http://dx.doi. org/10.1111/j.1523-1739.2004.00184.x

Bayne, E. M., and K. A. Hobson. 2001. Effects of habitat fragmentation on pairing success of ovenbirds: importance of male age and floater behavior. Auk 118:380-388. http://dx.doi. org/10.1642/0004-8038(2001)118[0380:EOHFOP]2.0.CO;2

Bender, D. J., T. A. Contreras, and L. Fahrig. 1998. Habitat loss and population decline: a meta-analysis of the patch size effect. Ecology 79:517-533. http://dx.doi.org/10.1890/0012-9658(1998) 079[0517:HLAPDA]2.0.CO;2

Benson, T. J., J. D. Brown, and J. C. Bednarz. 2010. Identifying predators clarifies predictors of nest success in a temperate passerine. Journal of Animal Ecology 79:225-234. http://dx.doi. org/10.1111/j.1365-2656.2009.01604.x

Birkhead, T. 2010. The magpies: the ecology and behaviour of Black-billed and Yellow-billed Magpies. A \& C Black, London, UK. 
Chalfoun, A. D., F. R. Thompson, and M. J. Ratnaswamy. 2002. Nest predators and fragmentation: a review and meta-analysis. Conservation Biology 16:306-318. http://dx.doi.org/10.1046/ j.1523-1739.2002.00308.x

Cox, W. A., F. R. Thompson, and J. Faaborg. 2012. Landscape forest cover and edge effects on songbird nest predation vary by nest predator. Landscape Ecology 27:659-669. http://dx.doi. org/10.1007/s10980-012-9711-x

Daubenmire, R. 1959. A canopy-coverage method of vegetational analysis. Northwest Science 33:43-64.

Davis, S. K. 2005. Nest-site selection patterns and the influence of vegetation on nest survival of mixed-grass prairie passerines. Condor 107:605-616. http://dx.doi.org/10.1650/0010-5422(2005) 107[0605:NSPATI]2.0.CO;2

Davis, S. K., R. M. Brigham, T. L. Shaffer, and P. C. James. 2006. Mixed-grass prairie passerines exhibit weak and variable responses to patch size. Auk 123:807-821. http://dx.doi. org/10.1642/0004-8038(2006)123[807:MPPEWA]2.0.CO;2

Davis, S. K., and W. E. Lanyon. 2008. Western Meadowlark (Sturnella neglecta). In A. Poole, editor. Birds of North America, Number 104. Cornell Lab of Ornithology, Ithaca, NY, USA.

Dawson, W. R., and F. C. Evans. 1960. Relation of growth and development to temperature regulation in nestling Vesper Sparrows. Condor 62:329-340. http://dx.doi.org/10.2307/1365163

Dobler, F. C., J. Eby, C. Perry, S. Richardson, and W. M. Vander Haegen. 1996. Status of Washington's shrub-steppe ecosystem: extent, ownership, and wildlife/vegetation relationships. Washington Department of Fish and Wildlife, Olympia, Washington, USA.

Donovan, T. M., P. W. Jones, E. M. Annand, and F. R. Thompson III. 1997. Variation in local-scale edge effects: mechanisms and landscape context. Ecology 78:2064-2075. http://dx.doi. org/10.1890/0012-9658(1997)078[2064:VILSEE]2.0.CO;2

Environmental Systems Research Institute(ESRI). 2011. ArcMap 10.0. Environmental Systems Research Institute, Redlands, California, USA.

Ewers, R. M., and R. K. Didham. 2006. Confounding factors in the detection of species responses to habitat fragmentation. Biological Reviews 81:117-142. http://dx.doi.org/10.1017/ S1464793105006949

Fischer, J., and D. B. Lindenmayer. 2007. Landscape modification and habitat fragmentation: a synthesis. Global Ecology and Biogeography 16:265-280. http://dx.doi.org/10.1111/

j.1466-8238.2007.00287.x

Fletcher, R. J. Jr., L. Ries, J. Battin, and A. D. Chalfoun. 2007. The role of habitat area and edge in fragmented landscapes: definitively distinct or inevitably intertwined? Canadian Journal of Zoology 85:1017-1030.

Foley, J. A., R. DeFries, G. P. Asner, C. Barford, G. Bonan, S. R. Carpenter, F. S. Chapin, M. T. Coe, G. C. Daily, H. K. Gibbs, J. H. Helkowski, T. Holloway, E. A. Howard, C. J. Kucharik, C. Monfreda, J. A. Patz, I. C. Prentice, N. Ramankutty, and P. K. Snyder. 2005. Global consequences of land use. Science 309:570-574. http://dx.doi.org/10.1126/science.1111772
Glennon, M. J., W. F. Porter, and C. L. Demers. 2002. An alternative field technique for estimating diversity of smallmammal populations. Journal of Mammalogy 83:734-742. http:// dx.doi.org/10.1644/1545-1542(2002)083<0734:AAFTFE >2.0.CO;2

Harrison, M. L., and D. J. Green. 2010. Vegetation influences patch occupancy but not settlement and dispersal decisions in a declining migratory songbird. Canadian Journal of Zoology 88:148-160. http://dx.doi.org/10.1139/Z09-125

Hartley, M. J., and M. L. Hunter. 1998. A meta-analysis of forest cover, edge effects, and artificial nest predation rates. Conservation Biology 12:465-469.

Helzer, C. J., and D. E. Jelinski. 1999. The relative importance of patch area and perimeter-area ratio to grassland breeding birds. Ecological Applications 9:1448-1458.

Hothorn, T., and K. Hornik. 2013. exactRankTests: Exact distributions for rank and permutation tests. The $\mathrm{R}$ Project for Statistical Computing, Vienna, Austria.

Ingelfinger, F., and S. Anderson. 2004. Passerine response to roads associated with natural gas extraction in a sagebrush steppe habitat. Western North American Naturalist 64:385-395.

Iverson, K., D. Curran, T. Fleming, and A. Haney. 2008. Sensitive ecosystems inventory Okanagan Valley: Vernon to Osoyoos 2000 2007. Pacific and Yukon Region Canadian Wildlife Service, Delta, British Columbia, Canada.

Kaiser, L. 1983. Unbiased estimation in line-intercept sampling. Biometrics 39:965-976. http://dx.doi.org/10.2307/2531331

Klug, P. E., S. L. Jackrel, and K. A. With. 2010. Linking snake habitat use to nest predation risk in grassland birds: the dangers of shrub cover. Oecologia 162:803-813. http://dx.doi.org/10.1007/ s00442-009-1549-9

Knick, S. T., D. S. Dobkin, J. T. Rotenberry, M. A. Schroeder, W. M. Vander Haegen, and C. Van Riper III. 2003. Teetering on the edge or too late? Conservation and research issues for avifauna of sagebrush habitats. Condor 105:611-634. http://dx.doi. org/10.1650/7329

Knick, S. T., and J. T. Rotenberry. 1995. Landscape characteristics of fragmented shrubsteppe habitats and breeding passerine birds. Conservation Biology 9:1059-1071. http://dx.doi.org/10.1046/ j.1523-1739.1995.9051041.x-i1

Knick, S. T., and J. T. Rotenberry. 2002. Effects of habitat fragmentation on passerine birds breeding in intermountain shrubsteppe. Studies in Avian Biology 25:130-140.

Knight, E. C. 2013. Impacts of habitat fragmentation by agriculture on breeding songbirds in the Okanagan sagebrush shrubsteppe. Thesis, Simon Fraser University, Burnaby, British Columbia, Canada.

Krannitz, P. G. 2007. Abundance and diversity of shrub-steppe birds in relation to encroachment of ponderosa pine. Wilson Journal of Ornithology 119:655-664. http://dx.doi.org/10.1676/06-129.1

Kuehl, A. K., and W. R. Clark. 2002. Predator activity related to landscape features in northern Iowa. Journal of Wildlife Management 66:1224-1234. http://dx.doi.org/10.2307/3802955 
Lahti, D. 2001. The "edge effect on nest predation" hypothesis after twenty years. Biological Conservation 99:365-374. http://dx. doi.org/10.1016/S0006-3207(00)00222-6

Lahti, D. C. 2009. Why we have been unable to generalize about bird nest predation. Animal Conservation 12:279-281. http://dx. doi.org/10.1111/j.1469-1795.2009.00286.x

Leopold, A. 1933. Game management. Charles Scribner's Sons, New York, New York, USA.

Lokemoen, J. T., and R. R. Koford. 1996. Using candlers to determine the incubation stage of passerine eggs. Journal of Field Ornithology 67:660-668.

Mabee, T. J. 1998. A weather-resistant tracking tube for small mammals. Wildlife Society Bulletin 26:571-574.

Major, R. E., and C. E. Kendal. 1996. The contribution of artificial nest experiments to understanding avian reproductive success: a review of methods and conclusions. Ibis 138:298-307. http://dx.doi.org/10.1111/j.1474-919X.1996.tb04342.x

Mazerolle, M. J. 2013. Package 'AICcmodavg'. The R Project for Statistical Computing, Vienna, Austria.

Nur, N., S. L. Jones, G. R. Geupel, and G. Geupel. 1999. Statistical guide to data analysis of avian monitoring programs. U.S. Department of the Interior, Fish and Wildlife Service, Washington, D.C., USA.

Paczek, S., and P. Krannitz. 2004. The importance of floristics to sagebrush breeding birds of the south Okanagan and Similkameen Valleys, British Columbia. U.S. Department of Agriculture Forest Service, Asilomar, California, USA.

Paton, P. W. C. 1994. The effect of edge on avian nest success: how strong is the evidence? Conservation Biology 8:17-26. http:// dx.doi.org/10.1046/j.1523-1739.1994.08010017.x

Pitkin, M., and L. Quattrini. 2010. Pocket guide to sagebrush birds. Rocky Mountain Bird Observatory and PRBO Conservation Science, Petaluma, California, USA.

R Core Team. 2012. R: a language and environment for statistical computing. The R Project for Statistical Computing, Vienna, Austria.

Renfrew, R. B., and C. A. Ribic. 2003. Grassland passerine nest predators near pasture edges identified on videotape. $A u k$ 120:371-383. http://dx.doi.org/10.1642/0004-8038(2003)120[0371: GPNPNP]2.0.CO;2

Ribic, C. A., R. R. Koford, J. R. Herkert, D. H. Johnson, N. D. Niemuth, D. E. Naugle, K. K. Bakker, D. W. Sample, and R. B. Renfrew. 2009. Area sensitivity in North American grassland birds: patterns and processes. Auk 126:233-244. http://dx.doi. org/10.1525/auk.2009.1409

Ries, L., R. J. Fletcher Jr., J. Battin, and T. D. Sisk. 2004. Ecological responses to habitat edges: mechanisms, models, and variability explained. Annual Review of Ecology, Evolution, and Systematics 35:491-522. http://dx.doi.org/10.1146/annurev. ecolsys.35.112202.130148

Rotenberry, J. T., M. A. Patten, and K. L. Preston. 1999. Brewer's Sparrow (Spizella brewerii). In A. Poole, editor. Birds of North
America Number 390. Cornell Lab of Ornithology, Ithaca, New York, USA.

Sauer, J. R., J. E. Hines, J. E. Fallon, K. L. Pardieck, D. J. J. Ziolkowski, and W. A. Link. 2014. The North American breeding bird survey, results and analysis 1966 - 2012, Version 02.19.2014. U.S. Geological Survey, Patuxent Wildlife Research Center, Laurel, Maryland, USA.

Shaffer, T. L. 2004. A unified approach to analyzing nest success. Auk 121:526-540. http://dx.doi.org/10.1642/0004-8038(2004)121 [0526:AUATAN]2.0.CO;2

Sisk, T. D., and J. Battin. 2002. Habitat edges and avian ecology: geographic patterns and insights for western landscapes. Studies in Avian Biology 25:30-48.

Smith, M. L. 2004. Edge effects on nest predators in two forested landscapes. Canadian Journal of Zoology 82:1943-1953. http://dx. doi.org/10.1139/z05-003

Spanhove, T., V. Lehouck, and L. Lens. 2009. Edge effects on avian nest predation: the quest for a conceptual framework. Animal Conservation 12:284-286. http://dx.doi.org/10.1111/ j.1469-1795.2009.00293.x

Sperry, J. H., D. A. Cimprich, R. G. Peak, and P. J. Weatherhead. 2009. Is nest predation on two endangered bird species higher in habitats preferred by snakes? Ecoscience 16:111-118. http://dx. doi.org/10.2980/16-1-3198

Stauffer, G. E., D. R. Diefenbach, M. R. Marshall, and D. W. Brauning. 2011. Nest success of grassland sparrows on reclaimed surface mines. Journal of Wildlife Management 75:548-557. http:// dx.doi.org/10.1002/jwmg.70

Stephens, S. E., D. N. Koons, J. J. Rotella, and D. W. Willey. 2004. Effects of habitat fragmentation on avian nesting success: a review of the evidence at multiple spatial scales. Biological Conservation 115:101-110. http://dx.doi.org/10.1016/S0006-3207(03)00098-3

Vander Haegen, W. M. 2007. Fragmention by agriculture influences reproductive success of birds in a shrubsteppe landscape. Ecological Applications 17:934-947. http://dx.doi. org/10.1890/06-0990

Vander Haegen, W. M., F. C. Dobler, and D. J. Pierce. 2000. Shrubsteppe bird response to habitat and landscape variables in eastern Washington, U.S.A. Conservation Biology 14:1145-1160. http://dx.doi.org/10.1046/j.1523-1739.2000.99293.x

Vander Haegen, W. M., M. A. Schroeder, and R. M. deGraaf. 2002. Predation on real and artificial nests in shrubsteppe landscapes fragmented by agriculture. Condor 104:496-506. http://dx.doi.org/10.1650/0010-5422(2002)104[0496:PORAAN]2.0. $\mathrm{CO} ; 2$

Van Horn, M. A., R. M. Gentry, and J. Faaborg. 1995. Patterns of Ovenbird (Seiurus aurocapillus) pairing success in Missouri forest tracts. Auk 112:98-106. http://dx.doi.org/10.2307/4088770

Weatherhead, P. J., and G. Blouin Demers. 2004. Understanding avian nest predation: why ornithologists should study snakes. Journal of Avian Biology 35:185-190. http://dx.doi.org/10.1111/ j.0908-8857.2004.03336.x 
Weatherhead, P. J., G. L. F. Carfagno, J. H. Sperry, J. D. Brawn, and S. K. Robinson. 2010. Linking snake behavior to nest predation in a Midwestern bird community. Ecological Applications 20:234-241. http://dx.doi.org/10.1890/09-0059.1

Wiewel, A. S., W. R. Clark, and M. A. Sovada. 2007. Assessing small mammal abundance with track-tube indices and markrecapture population estimates. Journal of Mammalogy 88:250-260. http://dx.doi.org/10.1644/06-MAMM-A-098R1.1

Wisdom, M., L. Suring, M. Rowland, R. Tausch, R. Miller, L. Schueck, C. W. Meinke, S. Knick, and B. Wales. 2003. A prototype regional assessment of habitats for species of conservation concern in the Great Basin ecoregion and Nevada, Version 1.1. U.S. Department of Agriculture Forest Service, Pacific Northwest Research Station, La Grande, Oregon, USA.

With, K. A. 1994. The hazards of nesting near shrubs for a grassland bird, the McCown's Longspur. The Condor 96:1009-1019. http://dx.doi.org/10.2307/1369110 